\title{
Az egyes vállalatok szerepe az aggregált ingadozásokban: magyarországi eredmények*
}

\author{
Czinkán Norbert
}

A jelen tanulmány azt vizsgálja, hogy a magyar vállalatok tevékenysége milyen szerepet játszott az aggregált ingadozások kialakulásában a 2000 és 2013 közötti időszakban. A tanulmány az árbevétel aggregált volatilitását makroágazati és vállalatspecifikus összetevöre bontva megállapítja, hogy az egyes vállalatokat érő sokkok jelentős mértékben járulnak hozzá az aggregált ingadozásokhoz. Az idioszinkratikus sokkok relativ hozzájárulása az árbevétel volatilitásához aggregált szinten 55,5 százalék a teljes gazdaság, és 56,4 százalék a feldolgozóipari ágazat esetében. A vállalati ingadozások az aggregált ingadozásokban föként az input-output kapcsolatok mechanizmusán keresztül érvényesülnek.

Journal of Economic Literature (JEL) kódok: E32, F12, F14, F41

Kulcsszavak: aggregált ingadozások, vállalati szintű sokkok, makroágazati sokkok

\section{Bevezetés}

Úgy túnik, hogy az egyes vállalatok fontos szerepet játszanak a gazdasági ciklusok elindításában. Friss kutatások sora igazolta, hogy a vállalatokat érő idioszinkratikus sokkok nem egyenlítődnek ki országos szinten, és ami a legfontosabb: nagymértékben hozzájárulnak az aggregált ingadozásokhoz (Gabaix 2011; Acemoglu et al. 2012; Di Giovanni et al. 2014). Vajon igaz ez Magyarország esetében is, amelynek gazdasága kicsi ugyan, de az egyik legnyitottabb a világon? Vagy a vállalati szintú ingadozások aggregált szinten elmosódnak, és a gazdasági ciklust inkább makro- és ágazati szintű sokkok alakítják?

A jelen tanulmány azt vizsgálja, hogy az egyes magyarországi vállalatokat érő sokkok érvényesülnek-e az aggregált ingadozásokban. E kérdés megválaszolásához $D i$ Giovanni és szerzőtársai (2014) módszertanát szorosan követve először a vállalati szintű éves növekedési rátákat idioszinkratikus és makroágazati összetevőre bon-

* Jelen cikk a szerző nézeteit tartalmazza, és nem feltétlenül tükrözi a Magyar Nemzeti Bank hivatalos álláspontját.

Czinkán Norbert az Alicantei Egyetem doktorandusza. E-mail: nczinkan@ua.es.

A szerző köszönetet kíván mondani a spanyol Gazdasági és Versenyügyi Minisztériumnak (BES-2013-064132), valamint a Magyar Nemzeti Bank Nyári Vendégkutatói Programjának anyagi támogatásáért. A jelen tanulmány a szerző nézeteit tartalmazza, és nem feltétlenül tükrözi a Magyar Nemzeti Bank hivatalos álláspontját. A megjelent változatban található hibákért a szerző felelős.

A kézirat első változata 2016. szeptember 16-án érkezett szerkesztőségünkbe.

DOI: http://doi.org/10.25201/HSZ.16.2.4063 
tom. Az idioszinkratikus sokkok számítása a vállalati szintű növekedés évenkénti átlagos ágazati növekedéshez viszonyított eltéréseként számítható ki. Segítségével valamennyi olyan esemény megragadható, amely az országos és ágazati szintű sokkoktól függetlenül befolyásolja az egyes vállalatok növekedését. Ezt követően az árbevétel vállalati szintű növekedését és annak idioszinkratikus és makroágazati összetevőjét országos szinten aggregálom, az egyes összetevőket az összárbevételhez való hozzájárulásuk szerint súlyozva. Végül kiszámítom az aggregált összetevők szórását, és megvizsgálom az idioszinkratikus, valamint a makroágazati összetevő relatív szórását az aggregált árbevétel-növekedési volatilitáshoz képest.

Az eredmények szerint vállalati szinten a vállalatokat érő sokkok döntő többsége idioszinkratikus, míg a makroágazati összetevő kisebb magyarázó erővel bír az egyes vállalatok árbevétel-növekedését illetően. Érdekes módon ezek az idioszinkratikus sokkok országos szinten nem mosódnak el. A vállalatspecifikus összetevő relatív szórása kiemelkedően magas: az aggregált ingadozások 55,5 százalékban magyarázhatók idioszinkratikus sokkokkal a teljes gazdaság esetében, és 56,4 százalékban a feldolgozóipari ágazat esetében. Ezek az eredmények a különböző növekedési és nyesési meghatározások, valamint a sokkokra adott heterogén válaszok beépítése tekintetében is robusztusak.

A tanulmány két fő csatornát különböztet meg, amelyeken keresztül az egyes vállalatok módosíthatják az árbevétel aggregált volatilitását. Egyrészt Acemoglu és szerzőtársai (2012, 2017), Carvalho (2014), valamint Barrot és Sauvagnat (2016) a kapcsolati csatornát hangsúlyozzák: szerintük az egyes vállalatokat az intput-output kapcsolatokon keresztül érő idioszinkratikus sokkok képesek aggregált ingadozásokat is előidézni. Az upstream vagy downstream partnert érő sokk a termelési hálózaton továbbterjedve felerősödik, végül pedig jelentős aggregált hatásokat vált ki. Másrészt Gabaix (2011) szerint a vállalatokat érő idioszinkratikus sokkok nem egyenlítődhetnek ki, mivel a vállalatméret eloszlása túlságosan vastag szélű (granularitási hipotézis): egyes óriásvállalatok olyan arányban járulnak hozzá a GDP növekedéséhez, hogy az őket ért sokkok meghatározhatják a gazdasági ciklust. ${ }^{1}$ Magyarországot illetően a kutatási eredmények arra utalnak, hogy az aggregált ingadozásokban az idioszinkratikus sokkok a kapcsolati csatornán keresztül érvényesülnek, amelynek hozzájárulása az aggregált idioszinkratikus összetevőhöz mintegy háromszor olyan jelentős, mint a granularitási csatornáé.

A közgazdászok többsége sokáig nem vizsgálta a vállalatok közötti különbségeket; az aggregált ingadozásokat főként az országok és ágazatok közötti különbségek mentén próbálták értelmezni. Jól dokumentált annak a lehetősége, hogy az egyes ágazatokat érő idioszinkratikus sokkok komoly aggregált hatással járjanak (Long és

\footnotetext{
${ }^{1}$ Példa erre Finnország esetében a Nokia, Dél-Korea esetében pedig a Samsung. 1998 és 2007 között a Nokia mintegy 25 százalékkal járult hozzá Finnország GDP-növekedéséhez, ahogyan a Samsung teljesítménye is igen jelentős Dél-Korea gazdasági sikere szempontjából.
} 
Plosser 1983; Stockman 1998; Koren és Tenreyro 2007a; Carvalho és Gabaix 2013). Az utóbbi időben a vállalati szintű adatok javuló minősége és hozzáférhetősége az egyes vállalatokra irányította a figyelmet. Melitz (2003) jelentős hatású munkájával kezdődően az újabb keletű tanulmányok rávilágítottak arra, hogy a vállalatok még a szorosabban vett ágazatokon és piacokon belül is meglepően heterogének, amivel további kutatásokat inspiráltak az egyes vállalatoknak a gazdasági ciklusok elindításában betöltött szerepével kapcsolatban. Gabaix (2011) elméleti és empirikus módszerekkel igazolta, hogy kellően „granuláris” gazdaság esetén a vállalati szintű sokkok nem feltétlenül egyenlítődnek ki országos szinten: az USA adatai alapján kimutatta, hogy a 100 legnagyobb vállalat komoly hatást gyakorol a GDP alakulására. Di Giovanni és szerzőtársai (2014) francia vállalati szintű mérleg- és vámadatok szélesebb körű adatbázisára támaszkodva azt állították, hogy a vállalati szintű ingadozások 80 százalékos relatív szórással érvényesülnek az aggregált volatilitásban. Hasonló megállapítások születtek Svédországra (Friberg - Sanctuary 2016), valamint Belgiumra (Magerman et al. 2016) vonatkozóan is.

Ezzel együtt továbbra is kevés az empirikus bizonyíték arra, hogy az egyes vállalatok aggregált ingadozásokat idéznek elő. A jelen tanulmány alapvető indíttatása, hogy gazdagítsa az egyes vállalatoknak a gazdasági ciklusok aggregációjában betöltött szerepével kapcsolatban kialakuló alkalmazott szakirodalmat. Legjobb ismereteim szerint tanulmányom elsőként közöl empirikus eredményeket az egyes vállalatok gazdasági ciklusokra gyakorolt hatásáról magyar vállalati szintű adatok alapján. Gondolhatnánk, hogy Magyarországon a vállalati ingadozások szerényebb mértékben járulnak hozzá a gazdasági ciklushoz, mivel az említett példákhoz viszonyítva a magyar gazdaság kisebb és nyitottabb, ami azt jelenti, hogy az ország jobban ki van téve a külföldi sokkoknak, így az idioszinkratikus sokkok jelentősége lényegesen kisebb, míg a makroágazati ingadozások fontosabb szerepet játszanak az aggregált volatilitásban. ${ }^{2}$ Magyarországon a makroágazati sokkok súlya (70 százalékos relatív szórás mellett) valóban nagyobb, mint Franciaországban (53 százalék) és Svédországban (58 százalék), ugyanakkor a vállalati szintű ingadozások is igen fontosak 56,4 százalék).

A tanulmány további részének felépítése a következő: a 2. szakasz bemutatja azt az ökonometriai modellt, amely alapján az árbevétel-növekedés vállalati rátái makroágazati és idioszinkratikus összetevőre bonthatók, majd megvizsgálja, hogy az így kapott összetevők milyen mértékben járulnak hozzá az aggregált árbevétel-növekedési volatilitáshoz. A 3. szakaszban az adatok leírása, a 4. szakaszban az eredmények összefoglalása, végül az 5 . szakaszban a következtetések megfogalmazása található.

\footnotetext{
${ }^{2}$ A Világbank szerint (http://data.worldbank.org/indicator/NE.TRD.GNFS.ZS?end=2013\&start=1960) 2013ban Magyarország a világ 13. legnyitottabb gazdasága volt: exportjának és importjának együttes volumene a GDP 165 százalékát tette ki, míg Franciaország nyitottsági mutatója 59 százalék, Svédországé 83 százalék, Belgiumé pedig 162 százalék volt. A GDP összevetéseképpen: Magyarországhoz képest Belgium gazdasága 3,7-szer, Svédországé 4-szer, Franciaországé 20-szor nagyobb.
} 


\section{2. Ökonometriai implementáció}

Di Giovanni és szerzőtársai (2014) módszertanát szorosan követve először a $\gamma_{f t}$ vállalati szintű éves növekedési rátákat makroágazati és idioszinkratikus összetevőre bontom: ${ }^{3}$

$$
\gamma_{f t}=\delta_{j t}+\varepsilon_{f t},
$$

ahol $\delta_{j t}$ a makroágazati keresleti és költségsokkokat magában foglaló ágazati átlagos növekedési ráta, $\varepsilon_{f t}$ pedig az idioszinkratikus sokk összetevője, amely egyszerűen a vállalati szintú árbevétel-növekedési ráta eltérését mutatja az ágazati átlagos növekedési rátához képest.4

A tanulmány végső célja annak értékelése, hogy a vállalatspecifikus sokkok $\left(\varepsilon_{f t}\right)$ milyen hatást gyakorolnak az aggregált ingadozásokra. Ennek érdekében először a makroágazati és idioszinkratikus növekedési ráták súlyozott összegeként kiszámítom az aggregált árbevétel-növekedést $\left(\gamma_{A t}\right)$ :

$$
\gamma_{A t}=\Sigma_{j} w_{j t-1} \delta_{j t}+\Sigma_{f} w_{f t-1} \varepsilon_{f t}
$$

ahol $w_{j t-1}$ a $j$ ágazat, $w_{f t-1}$ pedig az $f$ vállalat árbevételének aránya az összárbevételen belül. Lényeges, hogy az idioszinkratikus összetevő aggregált árbevétel-növekedési volatilitáshoz való relatív hozzájárulásának számszerűsítésénél az időben változó súlyozás bonyolítja az elemzést, mivel az ágazati és vállalati szintű értékesítés időben változó arányának hatása és az ezekhez kapcsolódó növekedési összetevők nem választhatók külön. Lehetséges viszont egy adott $\tau$ időszakhoz súlyokat rendelni a következő sztochasztikus folyamat mentén:

$$
\gamma_{A t \tau}=\Sigma_{j} w_{j \tau-1} \delta_{j t}+\Sigma_{f} w_{f \tau-1} \varepsilon_{f t},
$$

ahol a $w_{j \tau-1}$ és $w_{\mathrm{ft}-1}$ súly időben a $\tau-1$ szerinti értéken rögzített a $t$ időszaki sokkok figyelembevételével.

Ezután kiszámítom a $\gamma_{A t \mid \tau}$ sztochasztikus folyamat varianciáját, amelyet $\sigma_{A \tau}^{2}$ jelöl, majd azt felbontom az idioszinkratikus és makroágazati összetevő varianciájára:

$$
\sigma_{A \tau}^{2}=\sigma_{J \tau}^{2}+\sigma_{F \tau}^{2}+\operatorname{COV}_{\tau}
$$

ahol $\sigma_{j \tau}^{2}=\left(\Sigma_{j} w_{j \tau-1} \delta_{j t}\right)$ jelöli az aggregált makroágazati összetevő volatilitását, $\sigma_{F \tau}^{2}=\left(\Sigma_{f} w_{f \tau-1} \varepsilon_{f t}\right)$ a vállalatspecifikus volatilitást, és $\operatorname{COV}_{\tau}=\operatorname{Cov}\left(\Sigma_{j} w_{j \tau-1} \delta_{j t}, \Sigma_{f} w_{f \tau-1} \varepsilon_{f t}\right)$ az aggregáció különböző szintjein előidézett sokkok kovarianciáját.

\footnotetext{
${ }^{3} \mathrm{Az}$ adatok korlátozottsága miatt - rendeltetési hely szerinti exportadatok hiányában - nem alkalmazhatom pontosan ugyanazt a becslési eljárást, mint Di Giovanni és szerzőtársai (2014), akiknek a vállalatokra vonatkozóan az export-árbevételi adatok rendeltetési hely szerinti bontásban álltak rendelkezésére, és a vállalatok árbevétel-növekedési rátáit ágazati rendeltetési és idioszinkratikus összetevőkre bontották.

${ }^{4}$ Egy motiváló heterogén vállalati keretmodell az A. mellékletben található.
} 


\subsection{Becslés}

A becslési eljárás két lépésből áll. Az első lépés a vállalati szintű árbevétel-növekedési rátákat makroágazati és idioszinkratikus részre bontja, majd a második lépés a három tagot makroszinten aggregálja a hozzájuk tartozó ágazati és vállalati szintű fix súlyok alkalmazásával. Végül kiszámítom az aggregált makroágazati és idioszinkratikus összetevők relatív szórását az aggregált árbevétel-növekedési volatilitáshoz képest.

A $\delta_{j t}$ makroágazati sokk a $j$ ágazatban értékesítő összes vállalat árbevétel-növekedési rátájának átlaga. Az $\varepsilon_{f t}$ vállalatspecifikus sokk egyszerúen kiszámítható a $\gamma_{f t}$ eltéréseként a $\delta_{j t}$ képest, másképpen fogalmazva az ágazati év fix hatásait kiegyenlítő vállalati árbevétel-regresszió reziduumaként.

A $\sigma_{F \tau}^{2}$ becslője a $\Sigma_{f} w_{f \tau-1} \varepsilon_{f t}$ idősor $T$ realizációiból kapott minta varianciája, míg a $\sigma_{A \tau}^{2}$ és a $\sigma_{J \tau}^{2}$ becslője a $\gamma_{A t \tau}$, illetve $\Sigma_{j} w_{j \tau-1} \delta_{j t}$ realizációból kapott minta varianciája. Di Giovanni és szerzőtársai (2014) keretrendszere megengedi a keresztmetszeti és időbeli függőséget az adatgenerálási folyamat során, ezzel együtt feltételezett az $\varepsilon_{f t}$ és a $\delta_{j \mathrm{t}}$ (a növekedési rátákat leíró változók) stacionaritása. A szakirodalomban bemutatott egyéb megállapításokkal való összevethetőség érdekében az eredmények bemutatása minden esetben relatív szórás $\left(\sigma_{F \tau} / \sigma_{A \tau}\right)$ formájában történik.

\section{Az adatok leírása}

Az elemzés a Nemzeti Adó- és Vámhivatal (NAV) által a 2000 és 2013 közötti időszakban a kettős könyvvezetésre kötelezett magyarországi társaságoktól (a továbbiakban: vállalat) gyűjtött mérlegadatokat használja fel. Az adatbázis összesen 434956 vállalatot tartalmaz, ebből a vizsgált időszakban 45211 vállalat tartozott a feldolgozóipari ágazathoz. Az 1. ábrán látható, hogy az adatok alapján az aggregált reálárbevétel-növekedés - enyhén erősebb volatilitása ellenére - követi a magyar gazdasági ciklust, így adatbázisunk megfelelően reprezentatív az ország gazdaságára nézve.

A vállalati szintű reálárbevétel-növekedési ráták előállításához először a Központi Statisztikai Hivatal (KSH) által megadott kétjegyű ágazatspecifikus kibocsátási deflátorok alkalmazásával defláltam az árbevételi adatokat, majd két egymást követő év reálárbevétel-szintjének logaritmikus differenciáljaként kiszámítottam a $\gamma_{f t}$ árbevétel-növekedési rátákat. ${ }^{5}$ Mivel nem állnak rendelkezésemre fúziókkal és felvásárlásokkal kapcsolatos információk, az adatokat az árbevétel-növekedési ráták alsó és felső 1 százalékánál nyestem. ${ }^{6}$

\footnotetext{
${ }^{5}$ Az eredmények különféle növekedési definíciókkal szembeni robusztusságát a 4.4. szakasz mutatja be.

${ }^{6} \mathrm{~A}$ pontos küszöbértékek a $B$. mellékletben, az eredményeknek a különböző nyesési küszöbértékekkel szembeni robusztusságának bemutatása a 4.4. szakaszban található.
} 


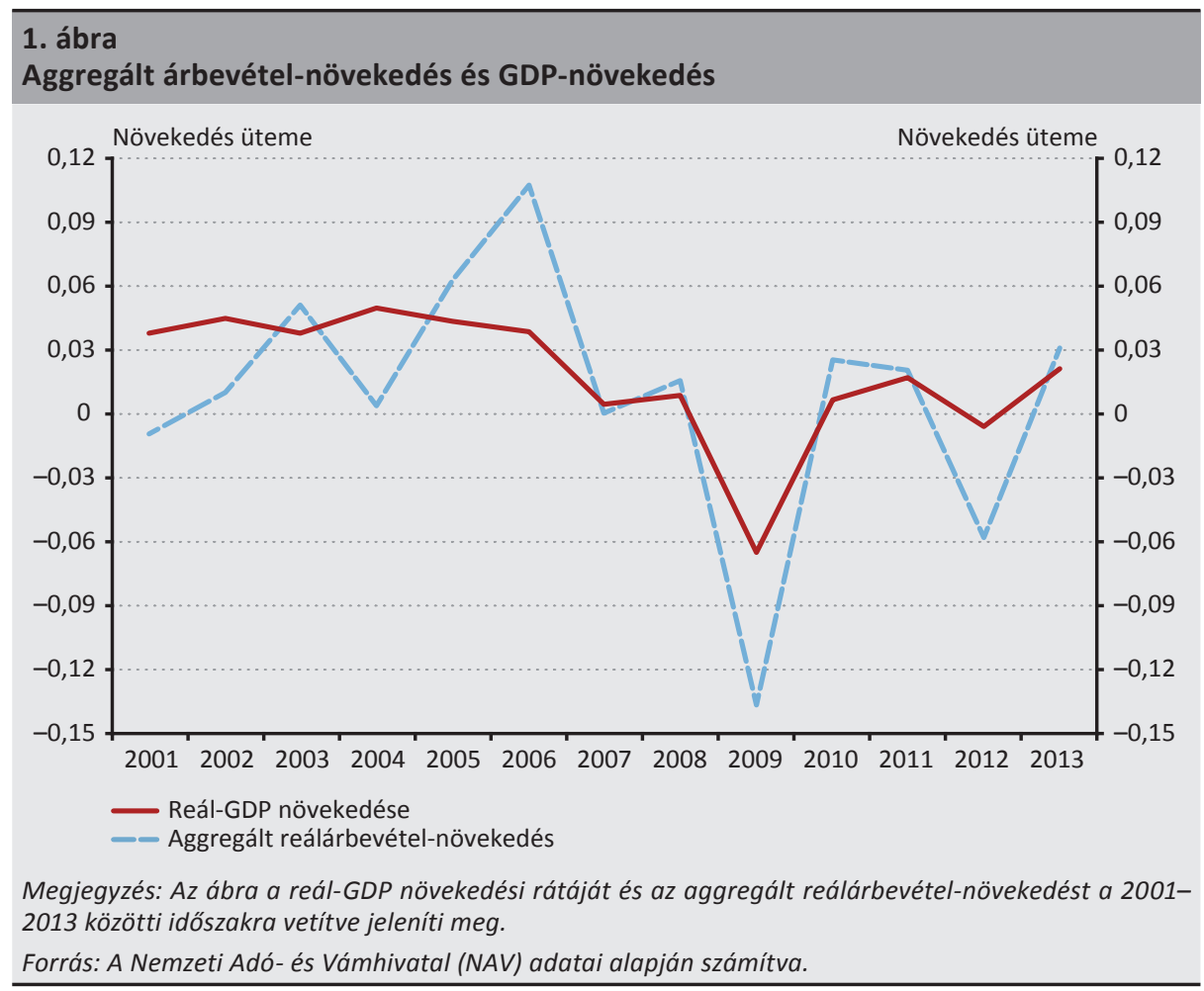

Az 1. táblázat a vállalati szintű reálárbevétel-növekedési ráták középértékét és szórását mutatja a teljes gazdaságra, valamint a feldolgozóipari ágazatra vonatkozóan. A reálárbevétel-növekedési ráta súlyozott átlaga a mintavételi időszakban $-3,78$ százalék (-1,63 százalék) volt a teljes gazdaság (feldolgozóipari vállalatok) esetében, ami az árbevételre a 2009. évben gyakorolt igen erőteljes negatív recessziós hatást tükrözi, míg az éves vállalati szintű reálárbevétel-növekedési ráta súlyozatlan átlaga 2,46 százalék (0,08 százalék) volt 0,6085 (0,5446) szórásérték(ek) mellett. A súlyozott és súlyozatlan átlagos növekedési ráták eltérése a gyorsabban növekvő kisvállalatokkal magyarázható (Haltiwanger 1997). A nagyvállalatokra kisebb mértékű ingadozás jellemző: a vállalatméret percentilis skáláján felfelé haladva a vállalatok növekedési volatilitása jellemzően mérséklődik, a 100, illetve 10 legnagyobb vállalat pedig még stabilabb. E megállapítások Franciaország (Di Giovanni et al. 2014), valamint Svédország (Friberg - Sanctuary 2016) esetében is érvényesek. ${ }^{7}$ A Herfindahl-Hirschman-index átlagos négyzetgyöke $(0,0667)$ alapján az árbevétel Magyarországon koncentráltabb, mint Franciaországban $(0,0301)$ vagy Svédországban $(0,055)$. A koncentrációs arányok közötti eltérés a feldolgozóipari ágazatok esetében még

\footnotetext{
${ }^{7}$ Magyarország esetében a megengedőbb nyesési küszöbértékek miatt a volatilitás mértéke nagyobb.
} 
jelentősebb. ${ }^{8}$ A nagyobb koncentráció arra utal, hogy a magyar gazdaság „granulárisabb", továbbá, hogy a nagyvállalatokat érő idioszinkratikus sokkok a vállalatméret vastag szélű eloszlásán keresztül érvényesülhetnek az aggregált ingadozásokban.

\begin{tabular}{|c|c|c|}
\hline \multicolumn{3}{|c|}{$\begin{array}{l}\text { 1.táblázat } \\
\text { A vállalati szintű éves reálárbevétel-növekedés leírása }\end{array}$} \\
\hline & Teljes gazdaság & Feldolgozóipar \\
\hline \multicolumn{3}{|c|}{ Középérték } \\
\hline Súlyozott & $-0,0378$ & $-0,0163$ \\
\hline Súlyozatlan & 0,0246 & 0,0008 \\
\hline \multicolumn{3}{|c|}{ Szórás } \\
\hline Átlag & 0,6085 & 0,5446 \\
\hline 0-20 méretpercentilis & 0,8387 & 0,7789 \\
\hline 20-40 méretpercentilis & 0,6038 & 0,5572 \\
\hline 40-60 méretpercentilis & 0,5380 & 0,4799 \\
\hline 60-80 méretpercentilis & 0,4963 & 0,4210 \\
\hline 80-100 méretpercentilis & 0,4210 & 0,3559 \\
\hline 100 legnagyobb & 0,3952 & 0,3387 \\
\hline 10 legnagyobb & 0,2815 & 0,2489 \\
\hline Átlagos $\mathrm{HHI}$ & 0,0667 & 0,1630 \\
\hline
\end{tabular}

Megjegyzés: A táblázat a $\gamma_{f t}$ éves vállalati szintű reálárbevétel-növekedés középértékét és szórását mutatja a teljes gazdaságra, valamint a feldolgozóipari ágazatra vonatkozóan. Az árbevétel-percentilisek képzése éves alapon történt. HHI: a vállalati szintű összárbevételek arányának Herfindahl-Hirschman-indexe.

Forrás: A Nemzeti Adó- és Vámhivatal (NAV) adatai alapján számítva.

A 2. táblázat az ágazati szintű reálárbevétel-növekedési ráták középértékeit és volatilitását, valamint a kétjegyű kóddal jelölt egyes ágazatok fontosságát foglalja össze. Az árbevétel aránya alapján az öt legnagyobb ágazat: nagy- és kiskereskedelem; villamos energia, gáz, gőz és meleg víz; jármű-kereskedelem, -javítás, üzemanyag-kiskereskedelem; híradástechnikai termék, készülék; közúti jármű. Az ágazatok mind növekedési ráta, mind volatilitás tekintetében heterogének. A legalább 1 százalékos arányt képviselő ágazatok között a leggyorsabb növekedést a következők érték el: pénzügyi közvetítés (9,02 százalék); híradástechnikai termék, készülék (5,68 százalék); gumi- és múanyag termékek (4,93 százalék); gépek, berendezések, valamint máshová nem sorolt villamos gép (4,39 százalék). Ezzel szemben a többi ágazattól elmaradó teljesítményt nyújtott a posta és távközlés ( $-2,35$ százalék), az építőipar (-1,69 százalék), a járműkereskedelem, -javítás, üzemanyag-kiskereskedelem (-1,11 százalék), valamint a nagykereskedelmi ágazat (-0,84 százalék). A legnagyobb vo-

\footnotetext{
${ }^{8}$ Lásd a vállalatméret és a vállalati árbevétel-növekedés eloszlását a $B$. mellékletben.
} 
latilitás az építőipar, a pénzügyi közvetítés, a fémfeldolgozási termék, valamint az ingatlanügyletek ágazatait jellemezte, míg a legstabilabb növekedési pálya az élelmiszerek és italok, a vegyi anyagok, termékek és koksz, kőolaj-feldolgozási termékek és nukleáris fútőanyagok, a kiskereskedelem, valamint a posta és távközlés ágazatai esetében volt megfigyelhető.

\section{2. táblázat \\ Ágazati szintű leíró statisztika}

\begin{tabular}{|c|c|c|c|c|c|}
\hline Kód & Ágazat megnevezése & Középérték & Szórás & Arány & Vállalatszám \\
\hline 51 & $\begin{array}{l}\text { Nagykereskedelem (gépjármű- } \\
\text { nagykereskedelem kivételével) }\end{array}$ & $-0,84 \%$ & 0,2354 & $17,91 \%$ & 40716 \\
\hline 52 & Kiskereskedelem & $0,72 \%$ & 0,1686 & $7,08 \%$ & 54376 \\
\hline 40 & Villamos energia, gáz, gőz és meleg víz & $3,40 \%$ & 0,1771 & $5,81 \%$ & 545 \\
\hline 50 & $\begin{array}{l}\text { Jármű-kereskedelem, -javítás, üzemanyag- } \\
\text { kiskereskedelem }\end{array}$ & $-1,11 \%$ & 0,2240 & $5,64 \%$ & 16903 \\
\hline 32 & Híradástechnikai termék, készülék & $5,68 \%$ & 0,2349 & $5,30 \%$ & 1031 \\
\hline 34 & Közúti jármű & $2,77 \%$ & 0,1951 & $5,23 \%$ & 375 \\
\hline 45 & Építőipar & $-1,69 \%$ & 0,3357 & $4,87 \%$ & 47862 \\
\hline 74 & Egyéb gazdasági szolgáltatás & $3,30 \%$ & 0,2694 & $4,47 \%$ & 77117 \\
\hline 15 & Élelmiszerek és italok & $-0,72 \%$ & 0,1717 & $4,44 \%$ & 5036 \\
\hline 23 & $\begin{array}{l}\text { Koksz, kőolaj-feldolgozási termékek és } \\
\text { nukleáris fütőanyagok }\end{array}$ & $2,45 \%$ & 0,1511 & $3,78 \%$ & 10 \\
\hline 24 & Vegyi anyagok, termékek & $3,27 \%$ & 0,1716 & $2,82 \%$ & 730 \\
\hline 64 & Posta és távközlés & $-2,35 \%$ & 0,1532 & $2,61 \%$ & 1631 \\
\hline 65 & Pénzügyi közvetítés (biztosítás nélkül) & $9,02 \%$ & 0,2753 & $2,32 \%$ & 1031 \\
\hline 01 & $\begin{array}{l}\text { Mezőgazdasági es vadgazdálkodási } \\
\text { termékek és kapcsolódó szolgáltatások }\end{array}$ & $0,25 \%$ & 0,2460 & $2,22 \%$ & 10339 \\
\hline 28 & Fémfeldolgozási termék & $2,19 \%$ & 0,2733 & $2,07 \%$ & 7463 \\
\hline 70 & Ingatlanügyletek & $0,24 \%$ & 0,2727 & $2,06 \%$ & 27971 \\
\hline 63 & $\begin{array}{l}\text { Szállítást kiegészítő tevékenység, } \\
\text { utazásszervezés }\end{array}$ & $2,55 \%$ & 0,2216 & $1,84 \%$ & 4968 \\
\hline 60 & Szárazföldi, csővezetékes szállítás & $3,08 \%$ & 0,1922 & $1,84 \%$ & 10799 \\
\hline 29 & Gép, berendezés & $3,91 \%$ & 0,2309 & $1,74 \%$ & 3794 \\
\hline 25 & Gumi- és műanyag termékek & $4,93 \%$ & 0,2168 & $1,47 \%$ & 2055 \\
\hline 31 & Máshová nem sorolt villamos gép & $4,39 \%$ & 0,2215 & $1,46 \%$ & 1115 \\
\hline 72 & Számítástechnikai tevékenység & $2,65 \%$ & 0,2541 & $1,25 \%$ & 16654 \\
\hline 92 & Szórakoztatás, kultúra, sport & $0,57 \%$ & 0,2052 & $0,96 \%$ & 12835 \\
\hline 26 & Nemfém ásványi termékek & $-1,36 \%$ & 0,2165 & $0,96 \%$ & 1811 \\
\hline 66 & $\begin{array}{l}\text { Biztosítás, nyugdíjalap (kivéve: kötelező } \\
\text { társadalombiztosítás) }\end{array}$ & $-1,05 \%$ & 0,2103 & $0,90 \%$ & 97 \\
\hline 55 & Szálláshely-szolgáltatás, vendéglátás & $1,02 \%$ & 0,1872 & $0,83 \%$ & 21282 \\
\hline
\end{tabular}




\section{2. táblázat}

\section{Ágazati szintű leíró statisztika}

\begin{tabular}{|c|c|c|c|c|c|}
\hline Kód & Ágazat megnevezése & Középérték & Szórás & Arány & Vállalatszám \\
\hline 22 & $\begin{array}{l}\text { Kiadói és nyomdai termékek és } \\
\text { szolgáltatások, egyéb sokszorosítás }\end{array}$ & $-5,73 \%$ & 0,1963 & $0,82 \%$ & 7349 \\
\hline 27 & Fémalapanyagok & $-6,94 \%$ & 0,2438 & $0,67 \%$ & 332 \\
\hline 21 & Papír és papírtermék & $-2,16 \%$ & 0,1590 & $0,47 \%$ & 541 \\
\hline 62 & Légi szállítás & $3,09 \%$ & 0,1754 & $0,44 \%$ & 102 \\
\hline 85 & Egészségügyi, szociális ellátás & $8,82 \%$ & 0,1777 & $0,43 \%$ & 16385 \\
\hline 90 & $\begin{array}{l}\text { Szennyvíz-, hulladékkezelés, köztisztasági } \\
\text { szolgáltatás }\end{array}$ & $3,92 \%$ & 0,2159 & $0,41 \%$ & 1134 \\
\hline 20 & Fatermék (kivéve bútor), fonott áru & $-2,13 \%$ & 0,2154 & $0,39 \%$ & 3161 \\
\hline 36 & $\begin{array}{l}\text { Bútor; máshová nem sorolt } \\
\text { feldolgozóipari termékek }\end{array}$ & $1,30 \%$ & 0,2244 & $0,37 \%$ & 3565 \\
\hline 33 & Műszer & $0,98 \%$ & 0,2400 & $0,34 \%$ & 1684 \\
\hline 67 & Pénzügyi kiegészítő tevékenység & $-7,20 \%$ & 0,2619 & $0,31 \%$ & 6324 \\
\hline 16 & Dohánytermékek & $6,17 \%$ & 0,1589 & $0,28 \%$ & 5 \\
\hline 17 & Textília & $-7,16 \%$ & 0,2192 & $0,28 \%$ & 1329 \\
\hline 41 & Víztermelés, -kezelés, -elosztás & $0,85 \%$ & 0,0984 & $0,28 \%$ & 350 \\
\hline 71 & Kölcsönzés & $2,39 \%$ & 0,2404 & $0,26 \%$ & 2091 \\
\hline 35 & Egyéb jármű & $4,21 \%$ & 0,2651 & $0,24 \%$ & 289 \\
\hline 18 & Ruházati termékek, szőrmék & $-9,67 \%$ & 0,2248 & $0,20 \%$ & 2717 \\
\hline 02 & $\begin{array}{l}\text { Erdészeti termékek, erdőgazdálkodás és } \\
\text { kapcsolódó szolgáltatások }\end{array}$ & $-0,21 \%$ & 0,1556 & $0,17 \%$ & 1881 \\
\hline 19 & Bőr, bőrtermék, lábbeli & $-1,35 \%$ & 0,2238 & $0,15 \%$ & 549 \\
\hline 73 & Kutatás, fejlesztés & $7,61 \%$ & 0,2769 & $0,14 \%$ & 2287 \\
\hline 80 & Oktatás & $2,35 \%$ & 0,2607 & $0,13 \%$ & 7277 \\
\hline 93 & Egyéb szolgáltatás & $1,81 \%$ & 0,1669 & $0,12 \%$ & 5392 \\
\hline 37 & Visszanyert másodlagos nyersanyagok & $-4,65 \%$ & 0,2462 & $0,12 \%$ & 263 \\
\hline 11 & $\begin{array}{l}\text { Nyers kőolaj és földgáz; kőolaj- és földgáz- } \\
\text { kitermelési szolgáltatás (kutatás nélkül) }\end{array}$ & $7,15 \%$ & 0,3139 & $0,12 \%$ & 34 \\
\hline 14 & $\begin{array}{l}\text { Kőfejtési termékek, vegyi és mútrágya- } \\
\text { alapanyagok, só, egyéb ásványbányászati } \\
\text { termékek }\end{array}$ & $-0,56 \%$ & 0,2816 & $0,11 \%$ & 433 \\
\hline 61 & Vízi szállítás & $-0,22 \%$ & 0,2196 & $0,03 \%$ & 117 \\
\hline
\end{tabular}

Megjegyzés: A táblázat az $\frac{1}{\mathrm{~T}} \sum_{t=2000}^{2013} \delta_{j t}$ ágazati szintű éves átlagos növekedést, valamint annak szórását mutatja be. Az ágazatok az "Arány” oszlop szerint vannak sorba rendezve, amely az egyes ágazatok árbevételének az összárbevételen belüli arányát mutatja.

Forrás: A Nemzeti Adó- és Vámhivatal (NAV) adatai alapján számítva. 


\section{Eredmények}

Ez a szakasz a főbb eredményeket ismerteti. Először kimutatom, hogy az aggregált volatilitás nagyrészt az árbevétel-növekedési ráta volatilitásának extenzív és intenzív határösszetevőre való bontását követően kapott intenzív határnak tudható be (4.1. szakasz). Ezután ismertetem a vállalati szintű eredményeket (4.2. szakasz), majd az összetevőket országos szinten aggregálva összefoglalom a vállalatspecifikus és makroágazati összetevő hozzájárulását az aggregált árbevételi volatilitáshoz (4.3. szakasz). A 4.4. szakaszban a vállalati szintű árbevétel-növekedés eltérő definíciója, eltérő nyesési szabályok, valamint az idioszinkratikus sokkok eltéri számítási módszertana alkalmazásával ellenőrzöm az eredmények robusztusságát. Végül a 4.5. szakaszban megvizsgálom azokat a lehetséges csatornákat, amelyeken keresztül az idioszinkratikus sokkok érvényesülhetnek a gazdasági ciklusokban.

\subsection{A vállalati összárbevétel felbontása intenzív és extenzív határra}

Di Giovanni és szerzőtársai (2014) módszertanát követve a $t$ időszakban az összes vállalat által elért $X_{t}$ aggregált összárbevétel az $X_{t} \equiv \Sigma_{f \in l_{t}} X_{f t}$ taggal írható fel, ahol $x_{f t}$ az $f$ vállalat $t$ évben elért árbevételét, $I_{t}$ pedig az $f$ vállalatok és $j$ kibocsátó ágazatok halmazát jelöli a $t$ időszakban. Először az aggregált árbevétel növekedési rátáját bontom fel intenzív és extenzív összetevőre. A $t$ időszaki intenzív összetevő a $t$ és $t-1$ évben egyaránt pozitív árbevételt elérő vállalatok árbevételének növekedési rátája, az extenzív határ pedig a vállalati árbevétel megjelenésének és eltűnésének hozzájárulása az összárbevételhez. Az összárbevétel növekedési rátájának logaritmikus differenciálja pontosan az alábbi módon bontható fel:

$\tilde{\gamma}_{A t} \equiv \ln \sum_{f \in \epsilon_{t}} x_{f t}-\ln \sum_{f \in t_{t-1}} x_{f t-1}=\ln \frac{\sum_{f \in t_{t / t-1}} x_{f t}}{\sum_{f \in \epsilon_{t / t-1}} x_{f t-1}}-\left(\ln \frac{\sum_{f \in \epsilon_{t / t-1}} x_{f t}}{\sum_{f \in \epsilon_{t}} x_{f t}}-\ln \frac{\sum_{f \in t_{t / t-1}} x_{f t-1}}{\sum_{f \in t_{t-1}} x_{f t-1}}\right)=\gamma_{A t}-\ln \frac{\pi_{t, t}}{\pi_{t, t-1}}$,

ahol $I_{t / t-1}$ a $t$ és $t-1$ évben egyaránt aktív vállalatok halmaza, $\pi_{t, t^{\prime}} \pi_{t, t-1}$ pedig a $t$ és $t-1$ időszakban a vállalatok ezen intenzív részmintája által megtermelt kibocsátás aránya. Az (5) egyenlet alapján az aggregált volatilitás intenzív és extenzív határa a következőképpen fejezhető ki:

$$
\tilde{\sigma}_{A}^{2}=\sigma_{A}^{2}+\sigma_{\pi}^{2}-2 \operatorname{cov}\left(\gamma_{A t}, g_{\pi t}\right),
$$

ahol $g_{\pi t}=\ln \left(\pi_{t, t} / \pi_{t, t-1}\right)$ az (5) egyenlet extenzív határösszetevője, $\sigma_{\pi}^{2}$ ennek varianciája, $\sigma_{A}^{2}$ az intenzív határ $\gamma_{A t}$ növekedési rátájának varianciája, $\operatorname{Cov}\left(\gamma_{A t}, g_{\pi t}\right)$ pedig a két tag kovarianciája. Intuitíve az összárbevétel volatilitása három elemből tevődik össze: a meglévő vállalatok árbevételének volatilitásából, a mintavételi időszakban történő belépések és kilépések volatilitásából, valamint e kettő potenciális kovarianciájából. 
meglepő. A 4. táblázat arra utal, hogy a vállalati teljesítményt az országspecifikus vagy ágazatspecifikus sokkok helyett inkább az olyan vállalatspecifikusabb jellemzők alakítják, mint a vállalat által előállított termékskálát érintő keresleti sokkok, a termelékenységi sokkok és a vezetői képességek, vagyis egy adott ágazaton belül a látszólag hasonló vállalatok ugyancsak eltérően viselkednek: a gyorsan növekvő ágazatokban a vállalatok jelentős része számottevő visszaesést tapasztal, míg a hanyatló ágazatokban sok vállalat gyorsan növekszik.

\begin{tabular}{|c|c|c|c|c|}
\hline \multicolumn{5}{|c|}{$\begin{array}{l}\text { 4. táblázat } \\
\text { A vállalati szintű reálárbevétel-növekedési ráták, valamint azok vállalatspecifikus és } \\
\text { makroágazati összetevóinek leírása }\end{array}$} \\
\hline \multicolumn{5}{|c|}{ Teljes gazdaság } \\
\hline Változók & $\begin{array}{l}\text { Megfigyelések } \\
\text { száma }\end{array}$ & Középérték & Szórás & Korreláció \\
\hline $\begin{array}{l}\text { Vállalati szintű árbevétel- } \\
\text { növekedési ráták }\end{array}$ & 1561644 & 0,0246 & 0,6085 & 1,0000 \\
\hline $\begin{array}{l}\text { Idioszinkratikus növekedési } \\
\text { összetevő }\end{array}$ & 1561644 & 0,0000 & 0,6040 & 0,9926 \\
\hline Makroágazati összetevő & 700 & 0,0340 & 0,1611 & 0,1216 \\
\hline \multicolumn{5}{|c|}{ Feldolgozóipari ágazat } \\
\hline Változók & $\begin{array}{l}\text { Megfigyelések } \\
\text { száma }\end{array}$ & Középérték & Szórás & Korreláció \\
\hline $\begin{array}{l}\text { Vállalati szintű árbevétel- } \\
\text { növekedési ráták }\end{array}$ & 213146 & 0,0008 & 0,5446 & 1,0000 \\
\hline $\begin{array}{l}\text { Idioszinkratikus növekedési } \\
\text { összetevő }\end{array}$ & 213146 & 0,0000 & 0,5387 & 0,9891 \\
\hline Makroágazati összetevő & 332 & 0,0058 & 0,1705 & 0,1470 \\
\hline
\end{tabular}

Megjegyzés: Az $\varepsilon_{f t}$ idioszinkratikus növekedési összetevő a $\gamma_{f t}$ éves vállalati szintü árbevétel-növekedési ráta eltérése a növekedés $\delta_{j t}$ makroágazati összetevőjéhez képest.

Forrás: A Nemzeti Adó- és Vámhivatal (NAV) adatai alapján számítva.

\subsection{A vállalatspecifikus sokkok szerepe az aggregált ingadozások előidézésében - a második lépés}

Miután az előző szakaszban igazolást nyert az idioszinkratikus sokkok elsődleges szerepe a vállalati szintű árbevétel-növekedés változékonyságában, a következő kérdés az, hogy a vállalati növekedés idioszinkratikus összetevője is hatással van-e az aggregált ingadozásokra.

Az idioszinkratikus összetevő relatív hozzájárulása az aggregált vállalatspecifikus összetevő szórása és az intenzív határon aggregált árbevétel-növekedés arányának időátlagaként számítható ki: 


$$
\sigma_{F \tau}^{r e l}=\frac{1}{T} \sum_{\tau=2001}^{2012} \frac{\sigma_{F \tau}}{\sigma_{A \tau}} .
$$

A makroágazati összetevő átlagos relatív szórása ugyanígy számítható ki:

$$
\sigma_{J \tau}^{r e l}=\frac{1}{T} \sum_{\tau=2001}^{2012} \frac{\sigma_{J \tau}}{\sigma_{A \tau}} .
$$

A főbb eredményeket az 5. táblázat mutatja be. Az aggregált vállalatspecifikus összetevő relatív szórásának időátlaga a teljes gazdaságot tekintve 56,5 százalék (a feldolgozóipari ágazatban 56,9 százalék), míg a makroágazati összetevő átlagos relatív hozzájárulása 69,5 százalék (73,1 százalék). ${ }^{9}$ Országos szinten a makroágazati sokkok relatív fontossága nőtt, míg az idioszinkratikus sokkok hozzájárulása mérséklődött, ugyanakkor a teljes időszakra vetítve a vállalatspecifikus összetevő aggregált hatása egyáltalán nem elhanyagolható; relatív fontossága a makroágazati sokkokéhoz mérhető. Di Giovanni és szerzőtársai (2014) megállapításaihoz képest a vállalati ingadozások általános hatása Magyarországon kisebb (56,5 százalék) mint Franciaországban (80,1 százalék), ezzel szemben a makroágazati tényezők relatív hozzájárulása nagyobb (69,5 százalék, illetve 52,9 százalék), ami a magyar gazdaságot a makroágazati sokkokkal szemben sérülékenyebbé tevő lényegesen nagyobb kereskedelmi nyitottságnak tulajdonítható.

\section{5. táblázat}

\section{A vállalatspecifikus sokkok aggregált hatása az aggregált volatilitásra}

\begin{tabular}{l|c|c|c|c} 
& \multicolumn{2}{|c|}{ Teljes gazdaság } & \multicolumn{2}{c}{ Feldolgozóipari ágazat } \\
\hline & Szórás & Relatív szórás & Szórás & Relatív szórás \\
\hline $\begin{array}{l}\text { Vállalati szintú árbevétel- } \\
\text { növekedési ráták }\end{array}$ & 0,0838 & 1,0000 & 0,0967 & 1,0000 \\
\hline $\begin{array}{l}\text { Idioszinkratikus növekedési } \\
\text { összetevő }\end{array}$ & 0,0464 & 0,5554 & 0,0540 & 0,5642 \\
\hline Makroágazati összetevő & 0,0566 & 0,6950 & 0,0702 & 0,7311 \\
\hline
\end{tabular}

Megjegyzés: A táblázat az aggregált vállalatspecifikus $\frac{1}{T} \sum_{\tau=2001}^{2012} \sigma_{F t}, a z \frac{1}{T} \sum_{\tau=2001}^{2012} \sigma_{j \tau}$ makroágazati összetevő, valamint az $\frac{1}{\mathrm{~T}} \sum_{\tau=2001}^{2012} \sigma_{A \tau}$ aggregált árbevétel-növekedési volatilitás átlagos szórását mutatja be abszolút $\left(\sigma_{F \tau}^{r e l}=\frac{1}{T} \sum_{\tau=2001}^{2012} \frac{\sigma_{F \tau}}{\sigma_{A \tau}}\right)$ és relatív $\left(\sigma_{J \tau}^{r e l}=\frac{1}{T} \sum_{\tau=2001}^{2012} \frac{\sigma_{\text {I }}}{\sigma_{A \tau}}\right)$ értékekkel.

Forrás: A Nemzeti Adó- és Vámhivatal (NAV) adatai alapján számítva.

\footnotetext{
${ }^{9} \mathrm{Az}$ aggregált árbevétel-növekedési ráták $\left(\sigma_{A \tau}\right)$, valamint a teljes gazdaságra vonatkozóan a (4) egyenletben meghatározott vállalatspecifikus $\sigma_{F \tau}$ és makroágazati $\sigma_{J \tau}$ összetevőik szórásának idősorát lásd a $B$. melléklet 3. ábráján.
} 


\subsection{Robusztusság}

Az eddigiek során az idioszinkratikus sokkokat egyszerűen az éves vállalati szintű árbevétel-növekedésnek a megfelelő ágazati növekedéshez viszonyított eltéréseként számítottam ki. A vállalatok azonban a különféle sokkokra eltérően reagálhatnak: a nagyobb és régebbi vállalatok rendelkeznek az árbevételt érő sokkok csillapításához szükséges tapasztalattal. Ezenkívül Vannoorenberghe (2012) megállapításának megfelelően a nemzetközi kereskedelmi tevékenységet folytató vállalatok a belföldi és külföldi sokkokat piacváltással fedezhetik abban az esetben, ha e sokkok nem korrelálnak tökéletesen egymással. Másfelől az exportőrök, valamint a régebbi és nagyobb vállalatok egyúttal termelékenyebbek is, így e vállalatoknak a fejlettebb gyártástechnológiák alkalmazása révén nagyobb esélyük van a sokkhoz való alkalmazkodásra. Számít emellett a hely is: a vállalati növekedésre egyaránt hatást gyakorolhatnak a helyi munkaerőpiaci feltételek, az infrastruktúra, valamint a helyi lakossági megtakarítások.

A sokkok által kiváltott heterogén reakciók, valamint a helyszín elkülönítése érdekében az $\varepsilon_{f t}$ idioszinkratikus növekedési összetevő becslését az alábbiak szerint módosítom:

$$
\gamma_{f t}=X_{f t}+d_{j t}+d_{r t}+\varepsilon_{f t}
$$

A $\gamma_{f t}$ árbevétel-növekedési rátákat a vállalati kovariánsok $X_{f t}$ halmazára regreszszálom, amely magában foglalja a kort, a vállalatméret helyettesítőjeként a $t-1$ időszaki összárbevétel logaritmusát, valamint az árbevétel exporthányadát. Ezenkívül a korábbiakhoz hasonlóan kiegyenlítem az ágazati év fix $d_{j t}$ hatásait, továbbá a regionális szintű, átmeneti helyi sokk kiküszöbölése céljából bevezetem a regionális év $d_{r t}$ fix hatásait. A 6. táblázat első sorában látható, hogy-meglepő módon - az idioszinkratikus sokkok gyakorlatilag változatlan mértékben járulnak hozzá az aggregált árbevétel-növekedési volatilitáshoz azt követően, hogy az időben változó helyi hatások és a sokkok által kiváltott heterogén vállalati reakciók kiküszöbölése a méret, a kor és az exportnyitottság kiegyenlítésével megtörtént. Az aggregált vállalati ingadozások relatív szórása a teljes gazdaságot tekintve 54,4 százalék (a feldolgozóipari ágazatban 56,5 százalék), míg a kiinduló eredmény 55,5 százalék (56,4 százalék) volt. 
gos növekedési rátával jellemezhetők (lásd az 1. táblázatot), így lehetséges, hogy a logaritmikus differenciál módszere alulbecsüli az egyes vállalatok hozzájárulását.

Az eredmények a különböző (a szélső 1 százalékon, 5 százalékon, illetve 10 százalékon kívüli árbevétel-növekedési ráták nyesését előíró) küszöbértékszabályok esetében is robusztusak. ${ }^{10} \mathrm{~A}$ vállalatspecifikus összetevő relatív hozzájárulása a teljes gazdaság esetében 55 százalék és 58 százalék, a feldolgozóipari ágazat esetében 52 százalék és 62 százalék között változik. A vállalati évre vonatkozó megfigyelések elhagyása nélkül ugyanezen értékek a várakozásoknak megfelelően magasak: a teljes gazdaság esetében 71,4 százalék, a feldolgozóipari ágazat esetében 78 százalék.

Figyelmet érdemel, hogy a szélsőséges értékek kezelésének e kritériumai jóval megengedőbbek a Di Giovanni és szerzőtársai (2014) által alkalmazottakhoz képest, akik a 100 százaléknál magasabb és a -50 százaléknál alacsonyabb növekedési rátákhoz tartozó megfigyeléseket hagyták el. ${ }^{11}$ A magyar adatok esetében ugyanakkor e kritériumok alkalmazását indokolatlanul korlátozónak tartom. Di Giovanni és szerzőtársai (2014) nyesési szabálya a megfigyelések egyharmadának elvesztését eredményezné, elsősorban a gyorsan növekedő mikro- és kisvállalkozásokét (a vállalati évre vonatkozó növekedési ráták 25 százaléka 100 százalék feletti, a megfigyelések több mint 8 százalék-a pedig -50 százaléknál alacsonyabb növekedési rátához kapcsolódik). Emellett a két gazdaság közötti strukturális eltérések miatt sem indokolt exogén módon alkalmazni a francia adatokra vonatkozó nyesési szabályt a magyar adatokra. A szélsőséges adatok kezelését tekintve saját megközelítésemben további eltérés, hogy nem hagyom el a 766000 EUR-nál (231 000 EUR-nál) kisebb éves árbevételű feldolgozóipari (szolgáltató) vállalatokat. ${ }^{12}$ Di Giovanni és szerzőtársai (2014) nyesési szabályát alkalmazva összehasonlíthatók a francia és magyar eredmények: Franciaországban az idioszinkratikus sokkok nagyobb relatív fontossággal bírnak a gazdasági ciklusok elindításában, mint Magyarországon. A vállalati ingadozások relatív szórása Franciaországban a teljes gazdaságot tekintve 80,1 százalék (a feldolgozóipari ágazatban 68,9 százalék), míg Magyarországon az idioszinkratikus sokkok aggregált árbevétel-növekedési volatilitáshoz való hozzájárulásának relatív szórása a teljes gazdaság esetében 52,3 százalék, a feldolgozóipari ágazat esetében pedig 61,7 százalék. Ahogyan korábban is említettem, az eltérések fő oka a két ország egymáshoz viszonyított kereskedelmi nyitottságában meglévő hatalmas különbségben kereshető: a magyar vállalatok esetében nagyobb a külföldi sokkok kockázata, így a vállalatokat érő idioszinkratikus sokkok kisebb szerepet kapnak az aggregált

${ }^{10}$ A vállalati szintű reálárbevétel-növekedés egyes küszöbértékekhez tartozó pontos értékei a B. mellékletben találhatók.

${ }^{11}$ Friberg - Sanctuary (2016) az árbevétel-növekedési adatokat 200 százalék felett és -50 százalék alatt nyeste a Di Giovanni és szerzőtársai (2014) által kapott eredményekkel való összehasonlíthatóság érdekében. Fontos azonban, hogy az előbbi küszöbértékszabály megengedőbb, így a két eredmény közvetlenül nem hasonlítható össze.

${ }^{12}$ Di Giovanni és szerzőtársai (2014) ezeket a megfigyeléseket a mérleg- és kereskedelmi adatok sikertelen megfeleltetése miatt hagyták el. Saját vizsgálatom esetében ez a probléma nem áll fenn. 
ingadozásokban. Ezzel együtt az idioszinkratikus sokkok hozzájárulása egyáltalán nem elhanyagolható, hatásuk nagysága a makroágazati zavarokéval összemérhető.

\subsection{Az idioszinkratikus sokkok aggregált ingadozásokban való érvényesülésének mechanizmusai}

Annak igazolása után, hogy az idioszinkratikus sokkok valóban szerepet játszanak a gazdasági ciklusok elindításában, a következő lépés annak megismerése, hogy a vállalati szintú ingadozások milyen mögöttes csatornákon keresztül alakítják az aggregált árbevétel-növekedési volatilitást. A vállalatméret „granuláris” eloszlásának köszönhető-e az, hogy egyes óriásvállalatok teljesítménye rendkívüli hatást gyakorol az ország gazdaságára, vagy pedig a terjedő sokkok az input-output kapcsolatokon keresztül erősödnek fel? A csatornák elkülönítése céljából a vállalati ingadozás $\sigma_{F \tau}^{2}$ aggregált összetevőjét variancia és kovariancia összetevőre bontom fel:

$$
\sigma_{F \tau}^{2}=\Sigma_{f} w_{f t-1}^{2} \operatorname{Var}\left(\varepsilon_{f t}\right)+\Sigma_{g} \Sigma_{f} w_{g t-1} w_{f t-1} \operatorname{Cov}\left(\varepsilon_{g t}, \varepsilon_{f t}\right), \quad f \neq g
$$

A (10) egyenlet szerint az aggregált idioszinkratikus sokkok volatilitása két csatornát foglal magában. Az egyik az egyedi sokkok varianciája, amelynek elnevezése Di Giovanni és szerzőtársai (2014) nyomán a DIRECT tag - ezt kizárólag a vállalatméret eloszlása határozza meg. A másik tag a vállalatok között terjedő sokkok kovarianciája, amelyet a továbbiakban LINK összetevőként említek. Az első tag a vállalatokat érő sokkok eloszlásának az aggregált volatilitásra gyakorolt hatását ragadja meg, míg a második a vállalatok közötti kapcsolatok hozzájárulását, vagyis a vállalatok közötti üzleti partnerség (vagy konkurencia) hatását, amely szerint a vállalatok valamelyikét érő sokk az adott vállalat hálózatában található egyéb vállalatokra is kihat, és/vagy az időben változó és átmeneti helyi sokkokat, például az azonos helyen található vállalatok egy adott csoportját érintő független eseményeket, amelyek hatással vannak árbevétel-növekedésükre.

A 7. táblázatból egyértelmúen látszik, hogy az idioszinkratikus sokk összetevőjét főként a LINK összetevő alakítja, míg a DIRECT csatorna elhanyagolható szerepet játszik az aggregált ingadozásokban. A LINK összetevő a vállalatspecifikus aggregátum átlagos varianciájának mintegy 88 százalékát magyarázza, míg a DIRECT összetevő mindössze 16 százalékát, az idioszinkratikus sokkok (1) egyenlet alapján történő becslése esetén. ${ }^{13}$ E megállapítások hasonlók Di Giovanni és szerzőtársai (2014) eredményeihez, azzal a különbséggel, hogy Franciaországban a LINK összetevő szorosabban követi a vállalatspecifikus összetevőt, mivel a francia gazdaság kevésbé koncentrált, így a nagyvállalatok még kevesebb eséllyel alakíthatják az aggregált ingadozásokat.

\footnotetext{
${ }^{13}$ A csatornák adatsorait lásd a B. melléklet 4. ábráján.
} 
A sokkok által kiváltott heterogén vállalati reakciók, valamint az azonos földrajzi körzetben müködő vállalatokat egyidejüleg érő helyi sokkok (9) egyenlet szerinti figyelembevételével a megállapítások azonosak, mindössze enyhe csökkenés figyelhető meg a LINK összetevő relatív fontosságában (84 százalék), valamint mérsékelt növekedés a DIRECT összetevőben (18 százalék). A fenti eredmények szintén Barrot - Sauvagnat (2016) megállapításait implikálják, illetve támasztják alá, amelyek szerint a vállalati szintű sokkok a vállalatok közötti vertikális és horizontális kapcsolatok mentén terjednek: az input-oldali beszállítókat érő sokk a downstream partnerekre is kihat, ami megfordítva is igaz: a nehézségekkel küzdő (vagy éppen növekedő) output-oldali vevő negatív, illetve pozitív hatást gyakorol az upstream partnerre. Az eredmények alapján úgy túnik, hogy a nagyvállalatokat érő sokkok a magyar gazdaság „granularitása” ellenére sem képesek önmagukban gazdasági ciklusokat elindítani, a vállalatok közötti kapcsolatok viszont igen: az egyes vállalatokat érő idioszinkratikus sokkok jelentős aggregált hatásokat válthatnak ki.

\begin{tabular}{|c|c|c|c|c|}
\hline \multicolumn{5}{|l|}{$\begin{array}{l}\text { 7. táblázat } \\
\text { A DIRECT és LINK összetevő }\end{array}$} \\
\hline & \multicolumn{2}{|c|}{ (1) } & \multicolumn{2}{|c|}{ (2) } \\
\hline & Variancia & Rel. var. & Variancia & Rel. var. \\
\hline Aggregált idioszinkratikus összetevő & 0,0022 & 1,0000 & 0,0020 & 1,0000 \\
\hline DIRECT & 0,0004 & 0,1632 & 0,0004 & 0,1843 \\
\hline LINK & 0,0019 & 0,8837 & 0,0017 & 0,8439 \\
\hline \multicolumn{5}{|c|}{ 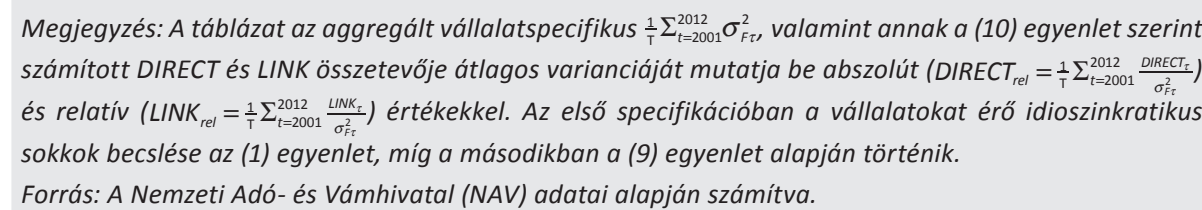 } \\
\hline
\end{tabular}

\section{Következtetések}

A jelen tanulmány célja annak elemzése volt, hogy a magyar vállalatok milyen szerepet játszanak az aggregált ingadozások kialakulásában. Az elemzés az idioszinkratikus sokkok aggregált árbevétel-növekedési volatilitásra gyakorolt hatását számszerűsítve megállapítja, hogy az egyes vállalatok szintjén a vállalatokat leginkább idioszinkratikus sokkok érik, míg a makroágazati tényezők másodlagos szerepet játszanak. Az eredmény arra utal, hogy az ágazati növekedéstől való eltérés vállalatonként számottevő mértékben változik: sok vállalat a recesszió ellenére növekedett, viszont konjunktúra idején is szép számmal találni hanyatló vállalatokat.

Érdekes módon azzal a széles körben elfogadott, évtizedes közhiedelemmel ellentétben, hogy az idioszinkratikus sokkok makroszinten kiegyenlítődnek, a tanulmány 
második lépésbeli eredményei azt jelzik, hogy a vállalati szintű sokkok is képesek a gazdasági ciklus alakítására, ezenfelül az aggregált árbevétel-növekedési volatilitáshoz való relatív hozzájárulásuk szintén igen jelentős. Annak ellenére, hogy Magyarország a világ egyik legnyitottabb gazdaságaként számottevő külföldi és ágazati sokkoknak van kitéve, az aggregált árbevételi volatilitás közel 50 százaléka vállalati szintú ingadozásoknak tulajdonítható, vagyis olyan eseményeknek, amelyek a makroágazati összetevőktől függetlenül hatnak a vállalatok teljesítményére.

Az eredmények arra utalnak, hogy a vállalatspecifikus tényezők aggregált ingadozásokhoz való nagymértékü hozzájárulását a vállalatok közötti kapcsolatok idézik elő: az egyes vállalatokat érő sokkok a termelési hálózatokon keresztül terjedve felerősödhetnek. A vállalatméret vastag szélü eloszlása kevésbé játszik fontos szerepet a gazdasági ciklusok elindításában. Bár a magyarországi árbevétel meglehetősen koncentrált, az eredmények azt is jelzik, hogy a nagyvállalatok teljesítménye önmagában csupán mérsékelt hatással van az aggregált volatilitásra.

A vállalati szintű sokkoknak a gazdasági ciklusok elindításában játszott meglepően fontos szerepe hangsúlyozza a vállalati szintű zavarokat meghatározó tényezők feltárására irányuló további kutatások indokoltságát. A vállalati szintű ingadozások forrásainak számszerűsítése a gazdaságpolitikai döntéshozók számára is értékes ismeretekkel szolgálhat.

\section{Felhasznált irodalom}

Acemoglu, D. - Carvalho, V. M. - Ozdaglar, A. - Tahbaz-Salehi, A. (2012): The network origins of aggregate fluctuations. Econometrica, 80(5): 1977-2016.

Acemoglu, D. - Ozdaglar, A. - Tahbaz-Salehi, A. (2017): Microeconomic origins of macroeconomic tail risks. The American Economic Review, 107(1): 54-108. http://dx.doi. org/10.1257/aer.20151086.

Barrot, J. N. - Sauvagnat, J. (2016): Input specificity and the propagation of idiosyncratic shocks in production networks. The Quarterly Journal of Economics, 131(3): 1543-1592. http://dx.doi.org/10.1093/qje/qjw018.

Carvalho, V. M. - Gabaix, X. (2013): The Great Diversification and its Undoing. American Economic Review, 103(5): 1697-1727. http://dx.doi.org/10.1257/aer.103.5.1697.

Carvalho, V. M. (2014): From micro to macro via production networks. The Journal of Economic Perspectives, 28(4): 23-48. http://dx.doi.org/10.1257/jep.28.4.23.

Castro, R. - Clementi, G. L. - Lee, Y. (2015): Cross-sectoral Variation in the Volatility of Plant Level Idiosyncratic Shocks. The Journal of Industrial Economics, 2015, 63(1): 1-29. http:// dx.doi.org/10.1111/joie.12069. 
Davis, S. J. - Haltiwanger, J. - Jarmin, R. - Miranda, J. (2007): Volatility and dispersion in business growth rates: Publicly traded versus privately held firms. NBER Macroeconomics Annual, Volume 21. MIT Press, 107-180. http://dx.doi.org/10.1086/ma.21.25554954.

Di Giovanni, J. - Levchenko, A. A. - Méjean, I. (2014): Firms, Destinations, and Aggregate Fluctuations. Econometrica, 82(4): 1303-1340. https://doi.org/10.3982/ecta11041.

Friberg, R. - Sanctuary, M. (2016): The contribution of firm-level shocks to aggregate fluctuations: The case of Sweden. Economics Letters, 147: 8-11. http://dx.doi. org/10.1016/j.econlet.2016.08.009.

Gabaix, X. (2011): The Granular Origins of Aggregate Fluctuations. Econometrica, 79(3): 733-772. https://doi.org/10.3982/ecta8769.

Haltiwanger, J. (1997): Measuring and analyzing aggregate fluctuations: the importance of building from microeconomic evidence. Federal Reserve Bank of St. Louis Review, 79(3): 55-77.

Kalemli-Ozcan, S. - Sørensen, B. - Volosovych, V. (2014): Deep financial integration and volatility. Journal of the European Economic Association, 12(6): 1558-1585. http://dx.doi. org/10.1111/jeea.12089.

Koren, M. - Tenreyro, S. (2007): Volatility and Development. Quarterly Journal of Economics, 122(1): 243-287. http://dx.doi.org/10.1162/qjec.122.1.243.

Koren, M. - Tenreyro, S. (2013): Technological diversification. The American Economic Review, 103(1): 378-414. http://dx.doi.org/10.1257/aer.103.1.378.

Long, J. B. - Plosser, C. I. (1983): Real Business Cycles. Journal of Political Economy, 91(1): 39-69. http://dx.doi.org/10.1086/261128.

Magerman, G. - De Bruyne, K. - Dhyne, E. - Van Hove, J. (2016): Heterogeneous firms and the micro origins of aggregate fluctuations. National Bank of Belgium, Working Paper Series, No. 312.

Melitz, M. J. (2003): The Impact of Trade on Intra-Industry Reallocations and Aggregate Industry Productivity. Econometrica, 71(6): 1695-1725. http://dx.doi.org/10.1111/14680262.00467.

Stockman, A. C. (1988): Sectoral and National Aggregate Disturbances to Industrial Output in Seven European Countries. Journal of Monetary Economics, 21(2-3): 387-409. http:// dx.doi.org/10.1016/0304-3932(88)90037-2.

Vannoorenberghe, G. (2012): Firm-level volatility and exports. Journal of International Economics, 86(1): 57-67. http://dx.doi.org/10.1016/j.jinteco.2011.08.013. 


\section{A. melléklet - A modell: többágazatos heterogén vállalati keretrendszer}

Ez a szakasz Di Giovanni és szerzőtársai (2014) szellemében egy egyszerūsített többágazatos heterogén vállalati modellt mutat be, amely alapján az aggregált árbevétel-növekedés makroágazati és vállalatspecifikus összetevőre bontható. ${ }^{14} \mathrm{~A}$ fogyasztóknál jelentkező hasznosság az alábbi Cobb-Douglas-függvénnyel határozható meg:

$$
U_{t}=\prod_{j=1}^{J}\left(C_{j t}\right)^{\varphi_{j t}},
$$

ahol $C_{j t}$ a $j$ ágazat fogyasztása a $t$ időszakban, $\varphi_{j t}$ pedig a $j$ ágazatot érő, időben változó keresleti sokk. Jelölje $Y_{t}$ a $t$ időszaki aggregált kiadásokat, $Y_{j t}$ pedig a $j$ ágazaton belüli kiadásokat. A Cobb-Douglas hasznossági függvény alapján a $j$ ágazaton belül kiadás $\varphi_{j t}$ törtrésze a teljes kiadásnak: $Y_{j t}=\varphi_{j t} Y_{t}$.

Az ágazatok a $t$ időpontban elérhető $f$ termékskálák $\omega_{\text {fjt }}$ keresleti sokkjának CES aggregátumaként határozhatók meg:

$$
C_{j t}=\left[\Sigma_{f \in \Omega_{j t}}\left(\omega_{f j t}\right)^{\frac{1}{\theta}}\left(C_{f t}\right)^{\frac{\theta-1}{\theta}}\right]^{\frac{\theta-1}{\theta}},
$$

ahol $\omega_{f j t}$ az $f$ termékskála időben változó keresleti sokkja.

Ebben a keretmodellben minden egyes vállalat egyedi termékskálát értékesít a $j$ ágazatban, így bizonyos mértékű piaci erővel rendelkezik. A vállalatok ezenkívül termelékenység szempontjából is heterogének, amit az időben változó $a_{f t}$ inputigény jelöl, amelynek költsége $c_{j t}$ a $j$ ágazatban és a $t$ időszakban. Az inputcsomagnak munkaerő-, illetve tőkeköltsége lehet. Így egy adott vállalat árbevételét a következő egyenlet adja:

$$
x_{f t}=\omega_{f j t} \frac{\varphi_{j t} Y_{t}}{P_{j t}}\left(\frac{\theta-1}{\theta} c_{j t} a_{f t}\right)^{1-\theta},
$$

ahol $P_{j t}$ a $j$ ágazatban a $t$ időszakban érvényes árszint.

Az $f$ vállalat $t-1$ és $t$ időszak közötti árbevétel-növekedési rátája logaritmikus differenciálként írható fel:

$$
\gamma_{f t}=\tilde{\delta}_{t}+\tilde{\delta}_{j t}+\varepsilon_{f t}
$$

${ }^{14}$ Di Giovanni és szerzőtársaihoz (2014) képest a saját megközelítésem annyiban tér el, hogy az adatok korlátozottsága miatt a vállalatok rendeltetési hely szerinti árbevétel-növekedési adatai helyett a bontást a teljes (belföldi és export) vállalati szintű árbevétel-növekedés alapján végzem az export rendeltetési helyére vonatkozó megfigyelések hiányában. 
ahol $\tilde{\delta}_{t}=\Delta \log Y_{t}$ a keresletet érő aggregált („makrogazdasági”) sokk, $\tilde{\delta}_{j t}=\Delta \log \varphi_{j t}+(1-\theta)\left(\Delta \log c_{j t}-\Delta \log P_{j t}\right)$ az ágazati keresleti és költségsokkokat ragadja meg, $\varepsilon_{f t}=\Delta \log \omega_{f t}+(1-\theta)\left(\Delta \log a_{f t}\right)$ pedig a vállalatspecifikus keresleti és költségsokk.

Fontos azonban, hogy a makrogazdasági $\tilde{\delta}_{t}$, valamint az ágazati $\tilde{\delta}_{j t}$ összetevő elkülönülten csak további korlátozásokkal becsülhető. Célom azonban hasonló Di Giovanni és szerzőtársai (2014) céljához annyiban, hogy végső soron nem e két összetevő, hanem a vállalatspecifikus sokkok aggregált árbevételi volatilitásra gyakorolt hatását vizsgálom. Végül a makroszintű és ágazati sokkot a $\delta_{j t}=\tilde{\delta}_{t}+\tilde{\delta}_{j t}$ makroágazati sokkban foglalom össze, amelynek mértékét az alábbi képlettel becsülöm:

$$
\gamma_{f t}=\delta_{j t}+\varepsilon_{f t}
$$

Így az $\varepsilon_{f t}$ idioszinkratikus sokkok a $\gamma_{f t}$ vállalati szintú árbevétel-növekedési ráták $\delta_{j t}$ ágazati átlagos növekedési rátához viszonyított eltéréseként becsülhetők.

\section{B. melléklet - Kiegészítő táblázatok és adatok}

8. táblázat
\begin{tabular}{l|c|c|c|c} 
A reálárbevétel-növekedés alsó és felső küszöbértékei \\
& \multicolumn{2}{|c|}{ Teljes gazdaság } & alsó & felső \\
\hline \multicolumn{1}{c|}{ percentilis } & alsó & felső & $-1,7836$ & 2,3081 \\
\hline $1 \%$ & $-2,0574$ & 2,7523 & $-0,8255$ & 0,9515 \\
\hline $5 \%$ & $-0,9282$ & 1,2185 & $-0,5377$ & 0,5688 \\
\hline $10 \%$ & $-0,5813$ & 0,7158 & $-0,2288$ & 0,2067 \\
\hline $25 \%$ & $-0,2258$ & 0,2418 & & $-0,0159$ \\
\hline $50 \%$ & \multicolumn{2}{|c|}{$-0,0079$} & & \\
\hline
\end{tabular}

Megjegyzés: A táblázat a vállalati szintű reálárbevétel-növekedési ráták alsó és felső percentiliseit mutatja a szélsőséges értékek kezeléséhez.

Forrás: A Nemzeti Adó- és Vámhivatal (NAV) adatai alapján számítva. 


\section{2. ábra}

Az árbevétel és az árbevétel-növekedési ráták eloszlása

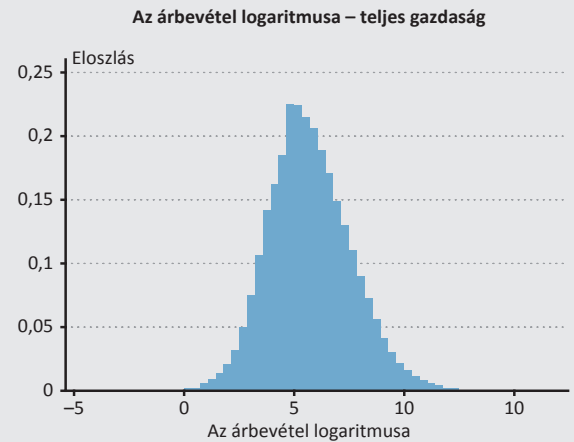

Az árbevétel logaritmusa - feldolgozóipari ágazat

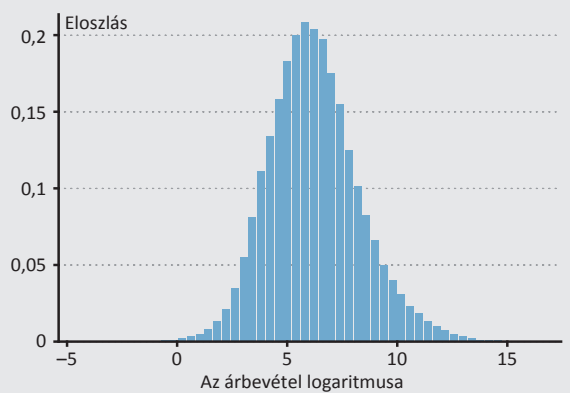

Árbvétel-növekedés - teljes gazdaság

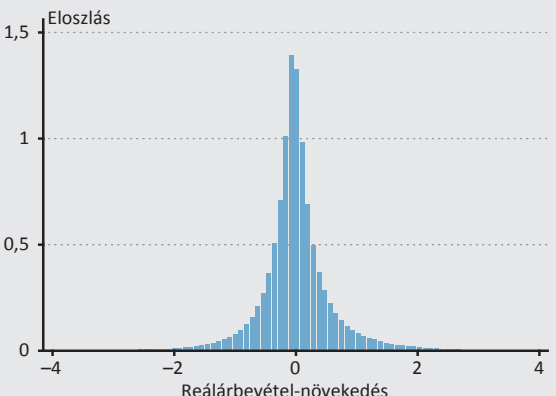

Árbvétel-növekedés - feldolgozóipari ágazat

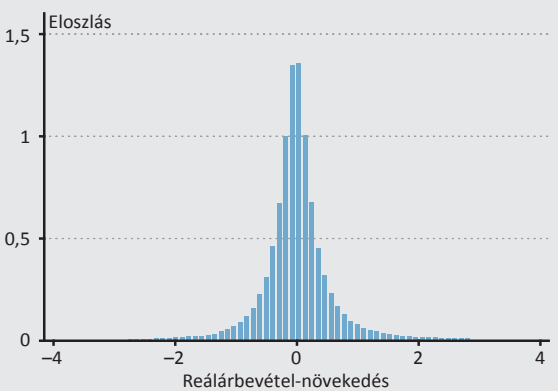

Megjegyzés: Az ábra az átlagos reálárbevétel logaritmusa (első oszlop), valamint a vállalati szintű reálárbevétel-növekedési ráta (második oszlop) eloszlását mutatja be a teljes gazdaságra (első sor) és a feldolgozóipari ágazatra (második sor) vonatkozóan.

Forrás: A Nemzeti Adó- és Vámhivatal (NAV) adatai alapján számítva. 


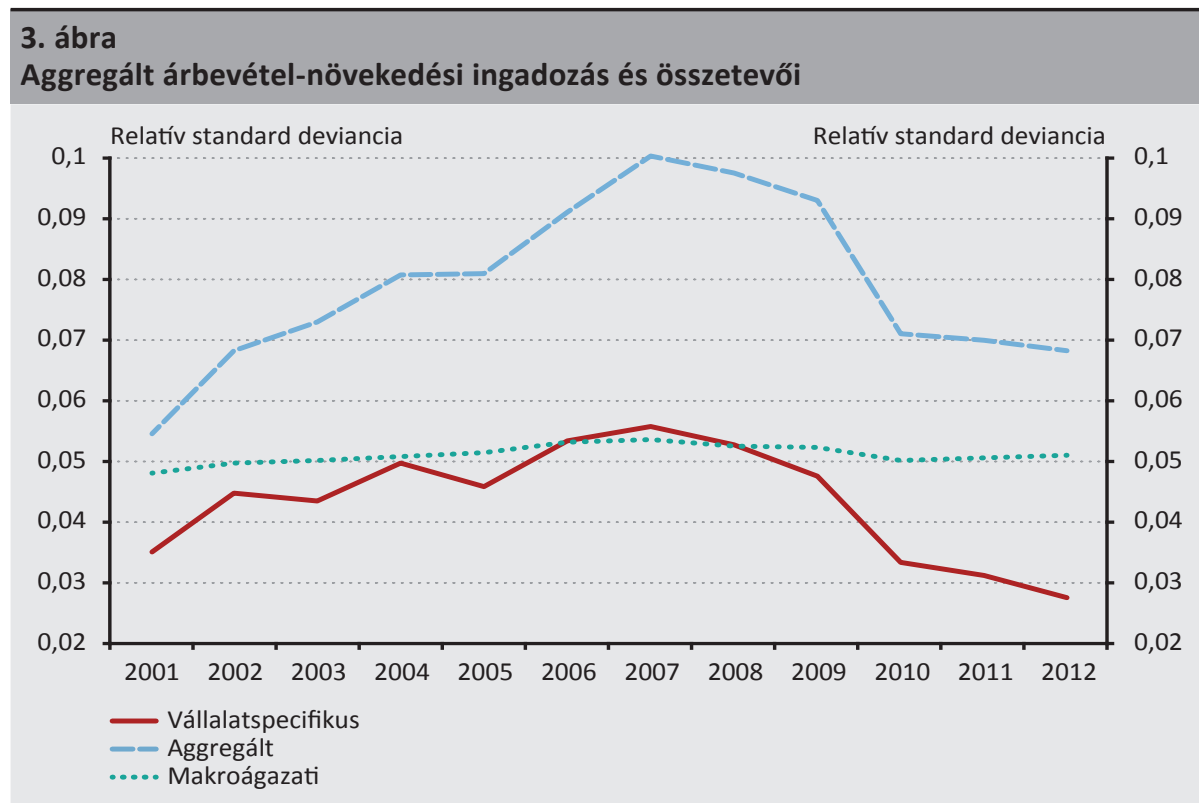

Megjegyzés: Az ábra a $\sigma_{A \tau}$ aggregált reálárbevétel-növekedési volatilitást, valamint annak vállalatspecifikus $\sigma_{F \tau}$ és makroágazati $\sigma_{J \tau}$ összetevőjét jeleníti meg a 2001-2012 közötti időszakra vetítve.

Forrás: A Nemzeti Adó- és Vámhivatal (NAV) adatai alapján számítva.

\section{4. ábra}

Az egyes volatilitások és kovarianciatagok hozzájárulása a vállalati ingadozásokhoz

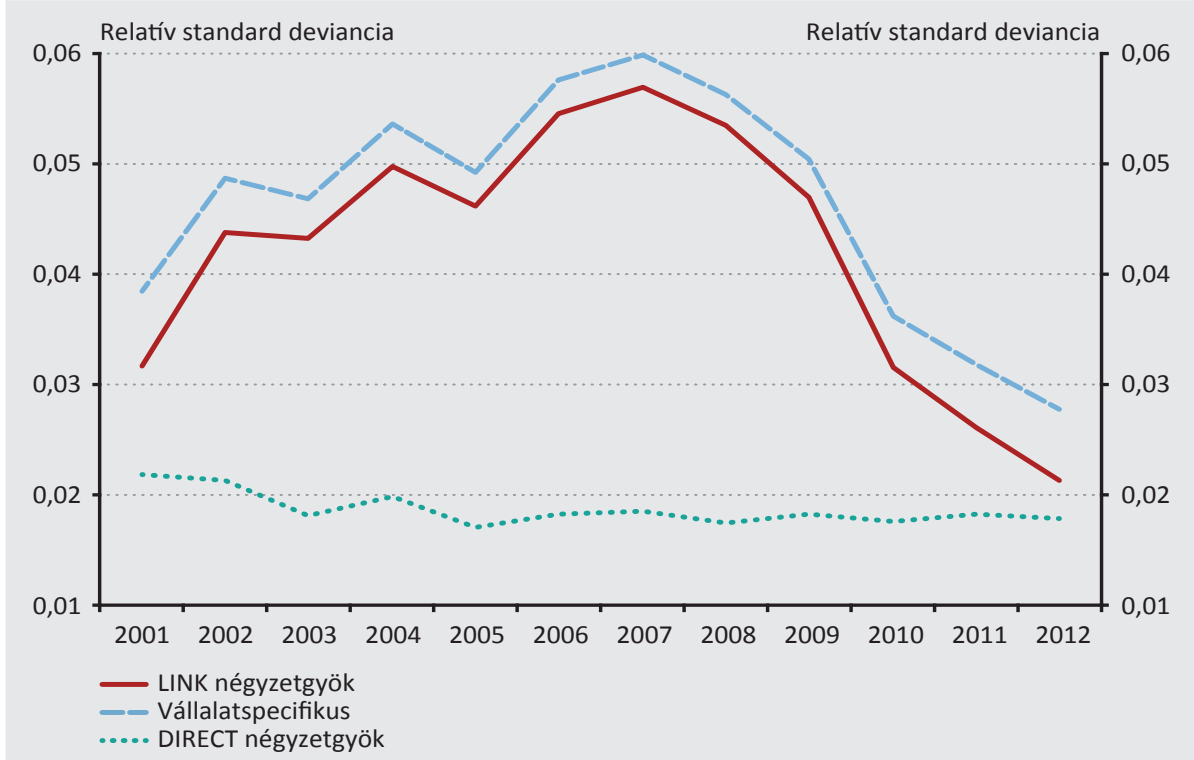

Megjegyzés: Az ábra a $\sigma_{F \tau}$ aggregált vállalati szintü ingadozások (10) egyenlet szerint számított DIRECT és LINK összetevő négyzetgyökére bontását jeleníti meg a 2001-2012 közötti időszakra vetítve.

Forrás: A Nemzeti Adó- és Vámhivatal (NAV) adatai alapján számítva. 